\title{
SISTEM PENDUKUNG KEPUTUSAN SPESIFIKASI BIJI JAGUNG BERKUALITAS TERBAIK DENGAN METODE MULTI ATTRIBUTE UTILITY THEORY
}

\author{
Chairul Imam ${ }^{1}$, Julius Santony ${ }^{2}$, Yuhandri $^{3}$ \\ ${ }^{1}$ Universitas Lancang Kuning Pekanbaru \\ ${ }^{2,3}$ Fakultas Ilmu Komputer, Universitas Putra Indonesia YPTK Padang \\ Email :chairulimam313@gmail.com, Juliussantony@yahoo.co.id, Yuhandri.yunus@gmail.com
}

\begin{abstract}
Abstrak.
Petani menjual biji jagung diperusahaan PT Charoen Pokphan Indonesia Tbk Medan,Biji jagung tersebut digunakan untuk campuran bahan baku pakan agar tercukupi nilai protein dan nutrisi pakan tersebut menjadi berkualitas. Perusahaan PT charoen Pokphan Indonesia Tbk Medan membali biji jagung ke petani dengan speksifikasi biji jagung berkualitas terbaik,agar tahu total harga biji jagung tersebut sesuai dengan kualitas yang dibutuhkan. Penelitian ini menetukan kriteria-kriteria jenis biji jagung berkualitas terbaik dan bagaimana menerapkan Metode Multi Attribute Utlity Theory Ke dalam sistem pendukung keputusan untuk menetukan kualitas biji jagung tersebut,untuk dapat membantu perusahaan PT charoen pokphan indonesia Tbk Medan dalam menentukan kualitas jenis biji jagung. Berdasarkan kriteria-kriteria yang telah ditetapkan pada perusahaan PT Charoen Pokphan Indonesia Tbk Medan untuk mendapatkan nilai biji jagung berkualitas terbaik dengan menggunakan grade 1 sampai grade 4 dan perangkingan. Hasil dari pengujian metode-metode tersebut adalah dihasilkan sebuah keputusan pada sebuah alternatif dengan nilai total sebesar $86.7 \%$. Maka metode ini dibutuhkan untuk mengevaluasi penentuan spesifikasi biji jagung berkualitas terbaik sehingga menghasilkan keputusan terbaik.
\end{abstract}

\section{Kata kunci: Sistem Pendukung Keputusan, Biji Jagung,Multi Attribute Utility Theory}

\begin{abstract}
.
Farmers sell corn kernels in the company of PT Charoen Pokphan Indonesia Tbk Medan, corn kernels are used to mix feed ingredients to meet the protein values and nutrition of these feeds to be of high quality. The company PT Charoen Pokphan Indonesia Tbk Medan buys corn kernels to farmers by specifying the best quality corn kernels, so they know the total price of corn kernels is in accordance with the quality needed. This research determines the criteria of the best quality types of corn kernels and how to apply the Multi Attribute Utility Theory to decision support systems to determine the quality of corn kernels, to be able to help the company PT Charoen Pokphan Indonesia Tbk Medan in determining the quality of corn kernels. Based on the criteria set out in the company PT Charoen Pokphan Indonesia Tbk Medan to obtain the best quality corn kernels using grade 1 to grade 4 and ranking. The results of testing these methods are produced a decision on an alternative with a total value of $86.7 \%$. So this method is needed to evaluate the determination of the best quality corn kernels to produce the best decisions.
\end{abstract}

Keywords: Decision Support System, Corn Beans, Multi Attribute Utility Theory

\section{Pendahuluan}

Teknologi komputer ini telah mampu mengolah data dalam jumlah yang banyak dalam waktu yang singkat. Teknologi komputer juga mempunyai media penyimpanan data yang mampu menyimpan data dalam jumlah besar.Hal-hal tersebut diatas membuat teknologi computer sangat diandalkan untuk mendukung kegiatan operasi perusahaan.Sistem Pendukung Keputusan ditandai dengan system interaktif berbasis komputer yang membantu pengambilan keputusan memanfaatkan data dan model untuk menyelesaikan suatu permasalahan.

Pada dasarnya Sistem Pendukung Keputusan dirancang untuk membantu dalam proses pengambilan keputusan yang dimulai dari memilih data yang relevan, mengidentifikasi masalah, menentukan pendekatan yang digunakan dalam pengambilan keputusan sampai mengevaluasi pemilihan. Sistem Pendukung keputusan ini tidak digunakan sebagai alat untuk pengambil seluruh keputusan, tetapi hanya

$\begin{array}{ll}\text { Dikirim } & : 2019-03-14 \\ \text { Diterima } & : 2019-03-20 \\ \text { Diterbitkan } & : 2019-04-01\end{array}$

DOI : https://doi.org/10.29165/komtekinfo.v5i2 
bersifat membantu untuk memberikan pertimbangan untuk mengambil sebuah keputusan (Roisdiansyah H.R.M., Widodo W.A., Hidayat N., 2017).

Metode Multi Attribute Utility Theory adalah proses pengambilan keputusan yang memungkinkan para pelakunya untuk mengevaluasi berbagai alternative persaingan guna mencapai tujuan tertentu. Dalam Metode Multi Attribute Utility Theory kita berusaha untuk membandingkan spesifikasi tersebut di bagi atas 3 bagian yaitu grade 1, grade 2, grade 3 dan perangkingan. Masing-masing grade mempunyai spesifikasi yang berbeda dan setiap grade juga mempunyai harga yang berbeda pula. Di grade ini la petani mengetahui jagung grade apa yang mereka bawah dan harga jual yang mereka dapatkan (Jannah R., Lusiana., 2015). Berdasarkan uraian diatas maka perlu dibangun suatu "Sistem Pendukung Keputusan Spesifikasi Biji Jagung Berkualitas Terbaik Dengan Metode Multi Attribute Utility Theory"

Dari latar belakang diatas penulis merumuskan permasalahan dalam penelitian ini yaitu :

1. Bagaimana perancangan Sistem Pendukung Keputusan agar dapat menentukan spesifikasi biji jagung berkualitas terbaik?

2. Bagaimana menerapkan metode Multi Attribute Utility Theory dalam menetukan Spesifikasi biji jagung berkualitas terbaik?

\section{Tinjauan Literatur}

Konsep yang mendasari dalam Sistem Pendukung Keputusan

1. Pengertian Sistem Pendukung Keputusan

Menurut Mat dan Watson, Sistem Penunjang Keputusan (SPK) merupakan suatu system interaraktif yang membantu pengambilan keputusan melalui penggunaan data dan model-model keputusan untuk memecahkan masalah-masalah yang sifatnya semi terstruktur dan tidak terstruktur (Alhamidi, 2016).

2. Metode Multi-Attribute Utility Theory (MAUT)

Menurut Nas C.,et al., (2018). Multi Attribute Utility Theory adalah teori utilitas (nilai kepuasan) yang dapat menentukan tindakan terbaik dalam pemecahan masalah dengan menetapkan utilitas untuk setiap alternatif yang mungkin terjadi dan menghitung kemungkinan utilitas terbaik . Teori utilitas mengevaluasi nilai akhir $\mathrm{v}(\mathrm{x})$ dari suatu objek $\mathrm{x}$ didefenisikan sebagai bobot yang dijumlahkan dengan suatu nilai yang relevan terhadap nilai dimensinya. Dengan menggunakan metode MAUT, dihasilkan urutan peringkat dari evaluasi alternatif.

Menurut Nofriansyah D (2016). Metode MAUT (Multi Attribute Utility Theory) merupakan metode yang fundamental selain metode MFEP(Multi Factor Evaluation Process). Metode ini terlihat memiliki proses penyelesaian yang merupakan penggabungan metode Analythical Hierarchy Process (AHP) dan metode Simple Additive Weighting (SAW). Adapun algoritma penyelesaian metode multi attribute utility theory ini yaitu:

1. Langkah 1 : Mendefinisikan terlebih dahulu kriteria-kriteria yang akan di jadikan sebagai tolak ukur penyelesaian masalah dan menentukan tingkat kepentingan dari setiap kriteria.

2. Langkah 2 : Menghitung Nilai Matriks Perbandingan dari masing-masing kriteria berdasarkan tabel nilai kepentingan (tabel saaty)

3. Langkah 3 : Menghitung nilai bobot kriteria (Wj)

4. Langkah 4 : Menghitung nilai bobot preferensi (Vi)

5. Langkah 5 : Perangkingkan

\section{Metodologi}

Tahapan proses daripenelitian ini mengalir sesuai dengan alur yang logis, tujuannya adalah untuk memberikan petunjuk yang jelas, teratur dan sistematis. Susunan tahapan ini sangat mempengaruhi mutu dari hasil yang akan diperoleh. Tahapan dari penelitian ini dapat dilihat pada gambar 3.1 dibawah ini: 


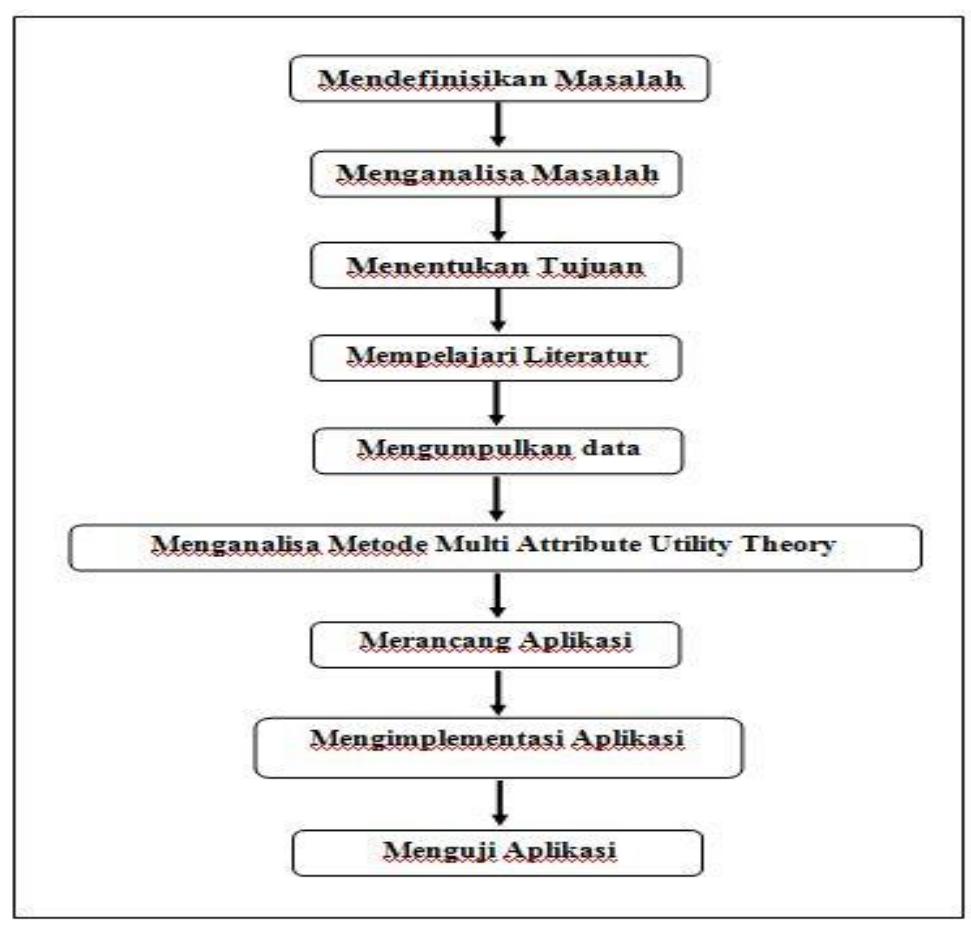

Gambar 3.1 Kerangka Alur Penelitian

\section{Hasil dan Diskusi}

\subsection{Tahapan Analisa dan Perancangan}

Tahapan analisa sistem dan perancangan sangat dibutuhkan didalam sebuah penelitian untuk mempengaruhi kualitas dan kuantitas dari sistem. Dapat dilihat pada gambar 3.1 berikut:

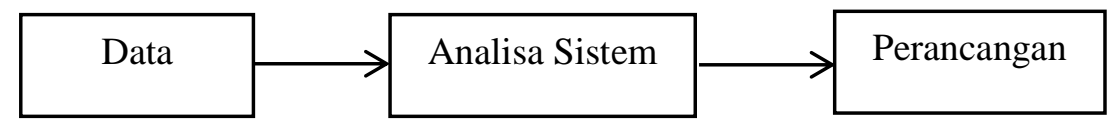

Gambar 4.1 Tahapan Analisa dan Perancangan

\subsection{Data Masukan}

Data yang diambil dalam penelitian ini adalah data penilaian lapangan yang diambil dari PT Charoen Pokphand Indonesia Tbk Medan. Data ini dipakai sebagai uji coba untuk mengetahui grade pada hasil akhir pengujian dengan dengan cara mengumpulkan nilai pada kertas penilaian perusahaan. Sistem yang diterapkan pada data ini diimplementasikan untuk mengetahui keunggulan metode Multi Attribute Utility Theory dalam melakukan pemilihan jenis jagung. Adapun data yang akan diolah sebagai kriteria dalam studi kasus ini sample corn, moisture, broken seed, moldy seed, damage seed, foreign material, aflatoxin ( $p p b)$. Berikut data sample corn pada perusahaan PT Charoen Pokphand Indonesia Tbk Medan. Berikut ini data nama corn dari perusahaan PT Charoen Pokphand Indonesia Tbk medan sebagai acuan penilai dari perusahaan tersebut pada tabel 4.1. 
Tabel 4.1 Data Nama Corn

\begin{tabular}{|c|c|c|c|c|c|c|}
\hline Nama Corn & Moisture & $\begin{array}{c}\text { Broken } \\
\text { Seed }\end{array}$ & $\begin{array}{c}\text { Moldy } \\
\text { Seed }\end{array}$ & $\begin{array}{c}\text { Damage } \\
\text { Seed }\end{array}$ & $\begin{array}{c}\text { Foreign } \\
\text { Material }\end{array}$ & $\begin{array}{c}\text { Aflatoxin } \\
(\mathbf{P p b})\end{array}$ \\
\hline Yellow corn 1 & $12.0 \%$ & $2.0 \%$ & $2.0 \%$ & $3.0 \%$ & $1.0 \%$ & $50 \%$ \\
\hline Yellow corn 2 & $13.0 \%$ & $4.0 \%$ & $4.0 \%$ & $6.0 \%$ & $2.0 \%$ & $100 \%$ \\
\hline Yellow corn 3 & $14.0 \%$ & $6.0 \%$ & $5.0 \%$ & $8.0 \%$ & $2.0 \%$ & $100 \%$ \\
\hline Wet Corn & $15.0 \%$ & $4.0 \%$ & $5.0 \%$ & $8.0 \%$ & $2.0 \%$ & $100 \%$ \\
\hline
\end{tabular}

Keterangan parameter ditabel 4.1 dijelaskan dibawah ini:

Nama Corn

Moisture

Broken Seed

Moldy Seed

Damage Seed

Foreign Material

Aflatoxin(Ppb)
: merupakan nama jagung

: kadar air yang terkandung di dalam biji jagung

: biji pecah / terbelah

: biji yang terkena / terkontaminasi dengan jamur yang timbul

: merusak benih

: material bahan yang tercampur dalam jagung seperti pecahan

Tungkul jagung

: jumlah bahan kimia yang terkontaminasi dengan jagung (part per billion) ini merupakan nama satuan dalam istilah aflatoxin

Data dibawah ini merupakan data sample corn yang akan dinilai spesifikasi biji jagung berkualitas terbaik dengan metode multi attribute utility theory. Pada tabel 4.2 dibawah ini:.

Tabel 4.2 Data Sample Corn

\begin{tabular}{|c|c|c|c|c|c|c|c|}
\hline No & $\begin{array}{c}\text { Sampel } \\
\text { Corn }\end{array}$ & Moisture & $\begin{array}{c}\text { Broken } \\
\text { Seed }\end{array}$ & $\begin{array}{c}\text { Moldy } \\
\text { seed }\end{array}$ & $\begin{array}{c}\text { Damage } \\
\text { seed }\end{array}$ & $\begin{array}{c}\text { Foreign } \\
\text { Material }\end{array}$ & $\begin{array}{c}\text { Aflatoxin } \\
\text { (Ppb) }\end{array}$ \\
\hline A1 & 617 & 13.7 & 4.4 & 1.9 & 2.1 & 0.5 & 50 \\
\hline A2 & 706 & 17.9 & 4.7 & 2.8 & 16 & 0.7 & 50 \\
\hline A3 & 710 & 14.5 & 4.6 & 4.5 & 0.9 & 0.5 & 20 \\
\hline A4 & 711 & 12.1 & 4.3 & 2.7 & 8 & 2 & 15 \\
\hline A5 & 712 & 13.8 & 4.6 & 1.7 & 2.8 & 0.3 & 15 \\
\hline A6 & 714 & 13.9 & 2.8 & 4.7 & 3.6 & 0.2 & 15 \\
\hline A7 & 717 & 14.2 & 4.6 & 2.8 & 1.7 & 0.7 & 25 \\
\hline A8 & 718 & 13.9 & 5 & 8.52 & 1.8 & 0.3 & 20 \\
\hline A9 & 719 & 14.3 & 6.2 & 4.3 & 1.8 & 0.2 & 15 \\
\hline A10 & 720 & 14.4 & 0.3 & 18 & 2.7 & 0.3 & 15 \\
\hline
\end{tabular}

Data sample corn adalah data sample corn data yang diacak oleh perusahaan PT Charoen Pokphand Indonesia Tbk Medan.

\subsubsection{Menghitung Nilai Matriks Perbandingan dari masing-masing kriteria berdasarkan tabel nilai kepentingan (tabel saaty) \\ Berikut ini adalah perhitungan matriks perbandingan berpasangan dari kriteria kemudian dari} level dibawahnya diambil elemen-elemen yang akan dibandingkan, misal K1 sampai K6 pada tabel 4.6 dibawah ini:.

Tabel 4.3 Matriks Perbandingan Berpasangan

\begin{tabular}{|l|c|c|c|c|c|c|}
\hline & K1 & K2 & K3 & K4 & K5 & K6 \\
\hline K1 & $1 / 1$ & $1 / 3$ & $1 / 5$ & $1 / 7$ & $1 / 7$ & $1 / 9$ \\
\hline
\end{tabular}




\begin{tabular}{|l|l|l|l|l|l|l|}
$\mathbf{K 2}$ & $3 / 1$ & $1 / 1$ & $1 / 3$ & $1 / 5$ & $1 / 7$ & $1 / 7$ \\
\hline $\mathbf{K 3}$ & $5 / 1$ & $3 / 1$ & $1 / 1$ & $1 / 3$ & $1 / 5$ & $1 / 7$ \\
\hline $\mathbf{K 4}$ & $7 / 1$ & $5 / 1$ & $3 / 1$ & $1 / 1$ & $1 / 3$ & $1 / 5$ \\
\hline $\mathbf{K 5}$ & $7 / 1$ & $7 / 1$ & $5 / 1$ & $3 / 1$ & $1 / 1$ & $1 / 3$ \\
\hline $\mathbf{K 6}$ & $9 / 1$ & $7 / 1$ & $7 / 1$ & $5 / 1$ & $3 / 1$ & $1 / 1$ \\
\hline
\end{tabular}

Hasil penjumlahan dari normalisasi matriks perbandingan berpasangan pada tabel 4.7 di bawah ini:.

Tabel 4.4 Normalisasi Matriks Perbandingan Berpasangan

\begin{tabular}{|c|c|c|c|c|c|c|}
\hline & K1 & K2 & K3 & K4 & K5 & K6 \\
\hline K1 & 1 & 0.33 & 0.2 & 0.14 & 0.14 & 0.11 \\
\hline K2 & 3 & 1 & 0.33 & 0.2 & 0.14 & 0.14 \\
\hline K3 & 5 & 3 & 1 & 0.33 & 0.2 & 0.14 \\
\hline K4 & 7 & 5 & 3 & 1 & 0.33 & 0.2 \\
\hline K5 & 7 & 7 & 5 & 3 & 1 & 0.33 \\
\hline K6 & 9 & 7 & 7 & 5 & 3 & 1 \\
\hline TOTAL & $\mathbf{3 2}$ & $\mathbf{2 3 . 3}$ & $\mathbf{1 6 , 5}$ & $\mathbf{9 . 7}$ & $\mathbf{4 . 8}$ & $\mathbf{1 . 9}$ \\
\hline
\end{tabular}

Menghitung nilai $w_{i}=\frac{1}{n} \sum_{l} a_{i j}$ berdasarkan table normalisasi matriks perbandingan.

Tabel 4.5 Nilai Matriks Perbandingan Berpasangan

\begin{tabular}{|c|c|c|c|c|c|c|}
\hline & K1 & K2 & K3 & K4 & K5 & K6 \\
\hline K1 & $1 / 32$ & $0.33 / 23.3$ & $0.2 / 16.5$ & $0.14 / 9.7$ & $0.14 / 4.8$ & $0.11 / 1.9$ \\
\hline K2 & $3 / 32$ & $1 / 23.3$ & $0.33 / 16.5$ & $0.2 / 9.7$ & $0.14 / 4.8$ & $0.14 / 1.9$ \\
\hline K3 & $5 / 32$ & $3 / 23.3$ & $1 / 16.5$ & $0.33 / 9.7$ & $0.2 / 4.8$ & $0.14 / 1.9$ \\
\hline K4 & $7 / 32$ & $5 / 23.3$ & $3 / 16.5$ & $1 / 9.7$ & $0.33 / 4.8$ & $0.2 / 1.9$ \\
\hline K5 & $7 / 32$ & $7 / 23.3$ & $5 / 16.5$ & $3 / 9.7$ & $1 / 4.8$ & $0.33 / 1.9$ \\
\hline K6 & $9 / 32$ & $7 / 23.3$ & $7 / 16.5$ & $5 / 9.7$ & $3 / 4.8$ & $1 / 1.9$ \\
\hline
\end{tabular}

Berikut ini merupakan hasil perhitungan dari tabel 4.7 untuk nilai matriks perbandingan berpasangan yang ada dibawah ini:.

$$
\left[\begin{array}{llllll}
0.03 & 0.01 & 0.01 & 0.01 & 0.03 & 0.06 \\
0.09 & 0.04 & 0.02 & 0.02 & 0.03 & 0.07 \\
0.16 & 0.13 & 0.06 & 0.03 & 0.04 & 0.07 \\
0.22 & 0.21 & 0.18 & 0.10 & 0.07 & 0.10 \\
0.22 & 0.30 & 0.30 & 0.31 & 0.21 & 0.17 \\
0.28 & 0.30 & 0.42 & 0.52 & 0.62 & 0.52
\end{array}\right]
$$

\subsubsection{Menghitung nilai bobot kriteria $(\mathrm{W} \mathbf{j})$}

Menghitung nilai bobot kriteria dengan cara menjumlahkan seluruh baris nilai matriks dan dibagi dengan jumlah kriteria seperti perhitungan dibawah ini:.

$0.03+0.01+0.01+0.01+0.03+0.06 / 6=0.027$

$0.09+0.04+0.02+0.02+0.03+0.07 / 6=0.047$

$0.16+0.13+0.06+0.03+0.04+0.07 / 6=0.083$

$0.22+0.21+0.18+0.10+0.07+0.10 / 6=0.148$

$0.22+0.30+0.30+0.31+0.21+0.17 / 6=0.252$

$0.28+0.30+0.42+0.52+0.62+0.52 / 6=0.444$

Hasil perhitungan dari bobot kriteria diatas $(\mathbf{W j})=(\mathbf{0 . 0 2 7} ; 0.047 ; 0.083 ; 0.148 ; 0.252 ; 0.444)$. 
Dibawah ini untuk menghitung bobot kriteria dan hasil bobot kriteria untuk menentukan jumlah hasil kriteria konsisten.

$\left[\begin{array}{llllll}0.03 & 0.01 & 0.01 & 0.01 & 0.03 & 0.06 \\ 0.09 & 0.04 & 0.02 & 0.02 & 0.03 & 0.07 \\ 0.16 & 0.13 & 0.06 & 0.03 & 0.04 & 0.07 \\ 0.22 & 0.21 & 0.18 & 0.10 & 0.07 & 0.10 \\ 0.22 & 0.30 & 0.30 & 0.31 & 0.21 & 0.17 \\ 0.28 & 0.30 & 0.42 & 0.52 & 0.62 & 0.52\end{array}\right] \times\left[\begin{array}{l}0.027 \\ 0.047 \\ 0.083 \\ 0.148 \\ 0.252 \\ 0.444\end{array}\right]=\left[\begin{array}{l}0.004 \\ 0.007 \\ 0.013 \\ 0.024 \\ 0.040 \\ 0.071\end{array}\right]$
$t=\frac{1}{6}+\frac{0.004}{0.027}+\frac{0.007}{0.047}+\frac{0.013}{0.083}+\frac{0.024}{0.148}+\frac{0.040}{0.252}+\frac{0.071}{0.444}=6.17$
$C i=\frac{6.17-6}{6-1}=0.033$

Nilai rata- rata kriteria konsistensi untuk menentukan pembagian hasil penilaian bobot kriteria agar mendapat hasil perhitungan Nilai Indeks kriteria konsisten(NIRK).pada tabel 4.9 dibawah ini:.

Tabel 4.6 Nilai Indeks Random Konsistensi (NIRK)

\begin{tabular}{|c|c|c|c|c|c|c|c|c|c|c|c|}
\hline No & 1 & 2 & 3 & 4 & 5 & 6 & 7 & 8 & 9 & 10 & 11 \\
\hline RC & 0,00 & 0,00 & 0,58 & 0,90 & 1,12 & 1,24 & 1,32 & 1,41 & 1,45 & 1,49 & 1,51 \\
\hline
\end{tabular}

Untuk $\mathrm{n}=6$, diperoleh NIRK $6=1.24$ sehingga dibagi hasil ci untuk mendapatkan hasil pernilaian bobot nilai normalisasi

$$
C_{R}=\frac{0.033}{1.24}=0.0266129032
$$

Nilai CR diatas adalah $\leq \mathbf{0 . 1}$, berarti bobot nilai normalisasi criteria konsisten 0.027 .

\subsubsection{Menghitung nilai bobot preferensi ( $\mathrm{Vi}$ )}

Untuk menghitung nilai bobot preferensi maka digunakan rumus:.

$$
v_{I}=\sum_{j=1}^{n} w_{j} x_{i j}
$$

Level ini terdiri dari kriteria-kriteria untuk menilai atau mempertimbangkan alternatif-alternatif yang ada dan menentukan alternatif-alternatif tersebut. maka diambil dari sample corn untuk dihitung hasil level penilai level alternatif A1 sampai A10 dengan menghitung nilai bobot preferensinya. Pada tabel 4.10. dibawah ini:.

Tabel 4.7 Penilaian Kriteria Sample Corn

\begin{tabular}{|c|c|c|c|c|c|c|c|}
\hline No & $\begin{array}{c}\text { Sampel } \\
\text { Corn }\end{array}$ & Moisture & $\begin{array}{c}\text { Broken } \\
\text { Seed }\end{array}$ & $\begin{array}{c}\text { Moldy } \\
\text { Seed }\end{array}$ & $\begin{array}{c}\text { Damage } \\
\text { seed }\end{array}$ & $\begin{array}{c}\text { Foreign } \\
\text { Material }\end{array}$ & $\begin{array}{c}\text { Aflatoxin } \\
(\mathbf{P p b})\end{array}$ \\
\hline A1 & 617 & 13.7 & 4.4 & 1.9 & 2.1 & 0.5 & 50 \\
\hline A2 & 706 & 17.9 & 4.7 & 2.8 & 16 & 0.7 & 50 \\
\hline A3 & 710 & 14.5 & 4.6 & 4.5 & 0.9 & 0.5 & 20 \\
\hline A4 & 711 & 12.1 & 4.3 & 2.7 & 8 & 2 & 15 \\
\hline A5 & 712 & 13.8 & 4.6 & 1.7 & 2.8 & 0.3 & 15 \\
\hline A6 & 714 & 13.9 & 2.8 & 4.7 & 3.6 & 0.2 & 15 \\
\hline A7 & 717 & 14.2 & 4.6 & 2.8 & 1.7 & 0.7 & 25 \\
\hline A8 & 718 & 13.9 & 5 & 8.52 & 1.8 & 0.3 & 20 \\
\hline
\end{tabular}


Chairul Imam ${ }^{1}$, Julius Santony ${ }^{2,}$ Yuhandri ${ }^{3}$

\begin{tabular}{|c|c|c|c|c|c|c|c|} 
A9 & 719 & 14.3 & 6.2 & 4.3 & 1.8 & 0.2 & 15 \\
\hline A10 & 720 & 14.4 & 0.3 & 18 & 2.7 & 0.3 & 15 \\
\hline
\end{tabular}

Nilai Bobot Kriteria $(\mathrm{Wj})=(\mathbf{0 . 0 2 5} ; \mathbf{0 . 0 4 5} ; 0.082 ; 0.148 ; 0.252 ; 0.444)$ nilai tersebut menjadi acuan perkalian dari masing-masing kriteria pada sample corn penilaian dibawah ini:.

$$
\begin{aligned}
617 & =(13.7 * 0.025)+(4.4 * 0.045)+(1.9 * 0.082)+(2.1 * 0.148)+(0.5 * 0.252)+(50 * 0.444) \\
& =\mathbf{2 3 . 2 8} \\
706 & =(17.9 * 0.025)+(4.7 * 0.045)+(2.8 * 0.082)+(16 * 0.148)+(0.7 * 0.252)+(50 * 0.444) \\
& =\mathbf{2 5 . 5 7} \\
710 & =(14.5 * 0.025)+(4.6 * 0.045)+(4.5 * 0.082)+(0.9 * 0.148)+(0.5 * 0.252)+(20 * 0.444) \\
& =\mathbf{1 0 . 0 6} \\
711 & =(12.1 * 0.025)+(4.3 * 0.045)+(2.7 * 0.082)+(8 * 0.148)+(2 * 0.252)+(15 * 0.444) \\
& =\mathbf{9 . 0 4} \\
712 & =(13.8 * 0.025)+(4.6 * 0.045)+(1.7 * 0.082)+(2.8 * 0.148)+(0.3 * 0.252)+(15 * 0.444) \\
& =\mathbf{7 . 8 2} \\
714 & =(13.9 * 0.025)+(2.8 * 0.045)+(4.7 * 0.082)+(3.6 * 0.148)+(0.2 * 0.252)+(15 * 0.444) \\
& =\mathbf{8 . 0 8} \\
717 & =(14.2 * 0.025)+(4.6 * 0.045)+(2.8 * 0.082)+(1.7 * 0.148)+(0.7 * 0.252)+(25 * 0.444) \\
& =\mathbf{1 2 . 2 9} \\
718 & =(13.9 * 0.025)+(5 * 0.045)+(8.52 * 0.082)+(1.8 * 0.148)+(0.3 * 0.252)+(20 * 0.444) \\
& =\mathbf{1 0 . 4 7} \\
719 & =(14.3 * 0.025)+(6.2 * 0.045)+(4.3 * 0.082)+(1.8 * 0.148)+(0.2 * 0.252)+(15 * 0.444) \\
& =\mathbf{7 . 9 5} \\
720 & =(14.4 * 0.025)+(0.3 * 0.045)+(18 * 0.082)+(2.7 * 0.148)+(0.3 * 0.252)+(15 * 0.444) \\
& =\mathbf{8 . 9 7}
\end{aligned}
$$

\subsubsection{Perangkingan}

Perangkingan dilakukan dengan mengambil nilai tertinggi dari hasil perhitugan alternatif diatas. Pada tabel 4.11 ditampilkan data perangkingan dan grade pada hasil perhitungan dibawah ini:.

Tabel 4.8 Hasil Perangkingan

\begin{tabular}{|c|c|c|c|c|}
\hline No & $\begin{array}{c}\text { Sampel } \\
\text { Corn }\end{array}$ & Nil.pref & Rangking & Grade \\
\hline 1 & 712 & 7.82 & Rangking 1 & Grade 1 \\
\hline 2 & 719 & 7.95 & Rangking 2 & Grade 1 \\
\hline 3 & 714 & 8.08 & Rangking 3 & Grade 1 \\
\hline 4 & 720 & 8.97 & Rangking 4 & Grade 1 \\
\hline 5 & 711 & 9.04 & Rangking 5 & Grade 1 \\
\hline 6 & 710 & 10.06 & Rangking 6 & Grade 1 \\
\hline 7 & 718 & 10.47 & Rangking 7 & Grade 1 \\
\hline 8 & 717 & 12.29 & Rangking 8 & Grade 2 \\
\hline 9 & 617 & 23.28 & Rangking 9 & Ditolak \\
\hline 10 & 706 & 25.57 & Rangking 10 & Ditolak \\
\hline
\end{tabular}




\subsection{PENGUJIAN}

Untuk membuktikan kebenaran pada tahap analisa dan perancangan sistem, maka perlu dilakukan pengujian untuk spesifikasi biji jagung berkualitas terbaik dengan metode multi attribute utility theory Aplikasi yang digunakan pada tahapan pengujian ini Berikut adalah tahapan-tahapan yang dilakukan pada pengujian ini:

1. Tampilan Halaman Login Pengguna

Tampilan di atas menunjukan bentuk dekripsi dari tampilan masuk sebelum pengguna memulai menggunakan Aplikasi pertama sekali pengguna diminta untuk mengisikan username dan password

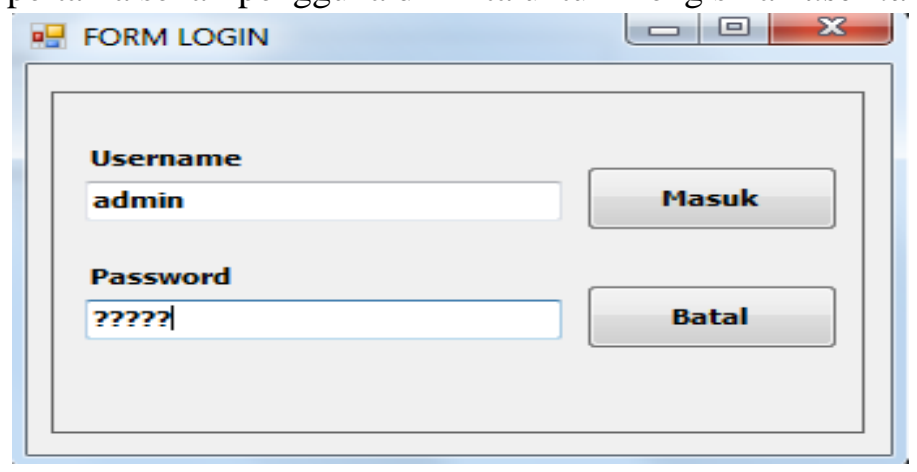

Gambar 5.1 Tampilan Halaman Login Pengguna

2. Tampilan Halaman Total Nilai Perhitungan Multi attribute utility theory

Form perangkingan hasil dari perhitungan bobot preferensinya dan sampel corn acak pada perusahaan PT Charoen Pokphand Indonesia Tbk Medan. untuk mendapat hasil spesifikasi biji jagung berkualitas terbaik dengan metode multi attribute utility theory.

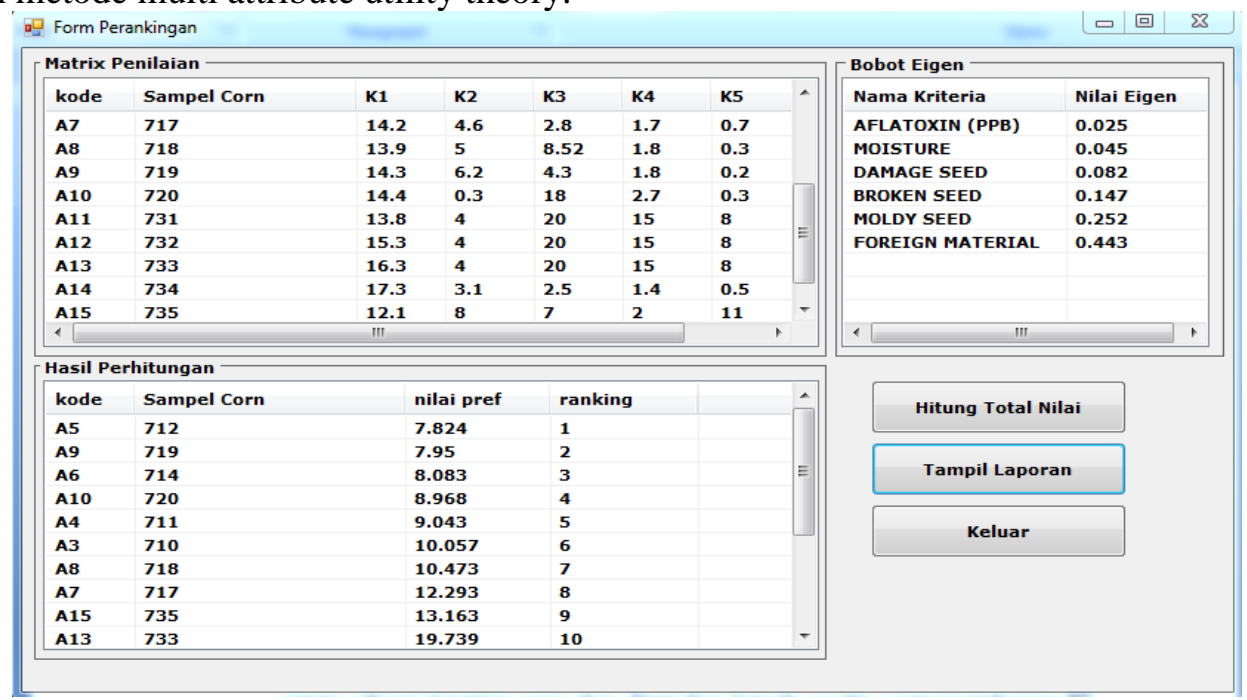

\section{Gambar 5.2 Tampilan Halaman form perangkingan}

3. Tampilan Halaman Laporan Hasil Perhitungan

merupakan tampilan halaman laporan hasil perhitungan yang dapat dicetak pada sistem sebagai lampiran yang akan diteruskan kepada quality control peruhasaan PT. Charoen Pokphand Indonesia Tbk Medan. 
Hasil Keputusan Menggunakan Metode MAUT

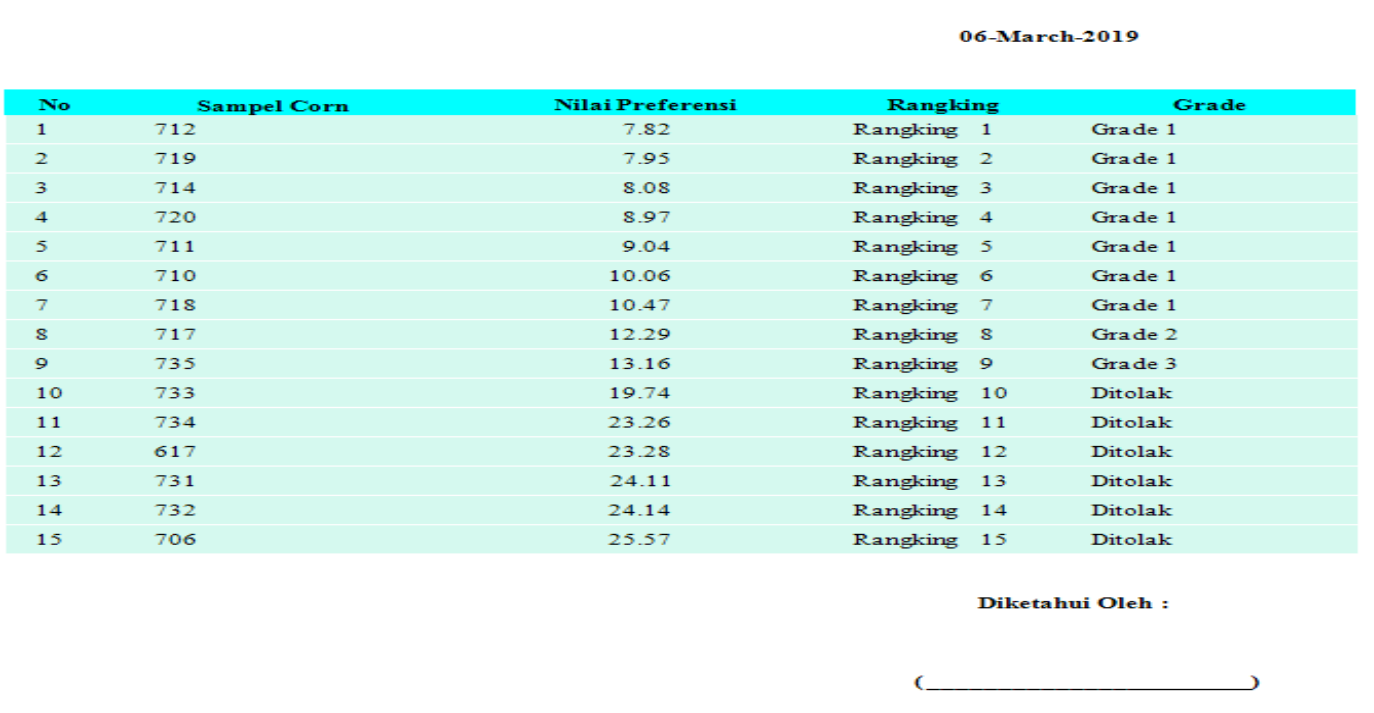

Gambar 5.3 Tampilan Halaman Laporan Hasil Perhitungan

hasil laporan tersebut mendapat hasil perangkingan yang nilai paling kecil rangking paling teratas dan nilai yang paling tinggi rangking terbawah. parameter penilai spesifikasi biji jagung berkualitas terbaik yang pertama 12.00 untuk grade 1, yang kedua 13.00 untuk grade 2,yang ketiga 14.00 untuk grade 3 dan yang terakhir 15.00 untuk grade 4 selebihnya ditolak oleh perusahaan PT Charoen Pokphand Indonesia Tbk.

\section{KESIMPULAN}

Setelah dilakukan analisa dan perancangan Sistem Pendukung Keputusan spesifikasi biji jagung berkualitas terbaik dengan metode multi attribute utility theory maka dapat diambil beberapa kesimpulan bahwa Perancangan Sistem Pendukung Keputusan dapat membantu didalam menentukan spesifikasi biji jagung yang dipilih untuk grade dan perangkingan. Penerapan Metode multi attribute utility theory dapat diterapkan dalam Sistem Pendukung Keputusan ini. hasil perhitungan menggunakan metode attribute utility theory spesifikasi biji jagung berkualitas terbaik, didapatkan hasil akurasi manual dan dengan software akurasi $86.7 \%$ sehingga menggunakan cara ini akan lebih mempermudah penyelesaian masalah pada spesifikasi biji jagung berkualitas terbaik di PT Charoen Pokphand Indonesia Tbk.

\section{DAFTAR PUSTAKA}

[1]. R Moh Andriawan Adikara, Muhammad Tanzil Furqon, Achmad Arwan.(2018). Sistem Pendukung Keputusan Pemilihan Varietas Unggul Jagung Hibrida Menggunakan Metode AHPSMART. Jurnal Pengembangan Teknologi Informasi dan Ilmu Komputer Vol. 2, No. 10, Oktober 2018.

[2]. Fitriyani. (2016). Sistem Pendukung Keputusan Pemilihan Mahasiswa Berprestasi di STMIK Atma Luhur Pangkalpinang dengan Menggunakan Metode Analytical Hierarchy Process (AHP). TEKNOSI, Vol. 02, No. 02, Agustus 2016.

[3]. Novri Hadinata. (2018). Implementasi Metode Multi Attribute Utility Theory (MAUT) Pada Sistem Pendukung Keputusan dalam Menentukan Penerima Kredit. Jurnal SISFOKOM, Volume 07, Nomor 02, September 2018.

[4].Abdul Halim Hasugian, Hendra Cipt H.(2018). Analisa Dan Perancangan Sistem Pendukung Keputusan Pemilihan Pasangan Hidup Menurut Budaya Karo Dengan Menggunakan Metode 
Chairul Imam ${ }^{1}$, Julius Santony ${ }^{2,}$ Yuhandri ${ }^{3}$

Analitycal Hierarchy Process (AHP). Jurnal Ilmu Komputer dan Informatika Volume: 02, Number :01, April 2018

[5]. Nia Komalasari. (2018). Sistem Pendukung Keputusan Kelaikan Terbang (SPK2T).Jurnal Industri Elektro dan Penerbangan 4 (1), 2018. 52, 2018.

[6]. Eka Andrita Gusdha M, Asep Wahyudin, Eddy Prasetyo Nugroho .(2016). Sistem Promosi Jabatan Karyawan dengan Metode Analytical Hierarchy Process (AHP) dan Multi-Attribute Utility Theory (MAUT) (Studi Kasus pada PT. Ginsa Inti Pratama). Jurnal Ilmu Komputer volume:01,Number : 02,Maret 2016.

[7]. Wahyu Halifathur Rachman, Joan Angelina Widians, Masnawati. (2017). Sistem Pendukung Keputusan Pemilihan Bibit Cabai Rawit Menggunakankan Metode Simple Additive Weighting (SAW) Berbasis Web. Prosiding Seminar Ilmu Komputer dan Teknologi Informasi Vol. 2, No. 1, Maret 2017

[8]. Ramadiani Ramadiani, Auliana rahmah. (2019). Sistem Pendukung keputusan pemilihan tenaga kesehatan teladan menggunakan metode Multi Attribute Utility Theory. Jurnal Ilmiah Teknologi Sistem Informasi 5 (1) 2019 1-12

[9]. Chairun Nas, Sarjon Defit, Julius Santony. (2018). Evaluasi Mutasai Jabatan Anggota Kepolisian Menggunakan Metode Profile Matching dan Multi Attribute Utility Theory. Jurnal Sains, Vol. 16, No. 1, Desember 2018. 